九州大学学術情報リポジトリ

Kyushu University Institutional Repository

\title{
Antitumoric Potentiality of Some Ascorbate Derivatives
}

Omura, Hirohisa

Food Chemistry Institute, Faculty of Agriculture, Kyushu University

Tomita, Yoshifumi

Food Chemistry Institute, Faculty of Agriculture, Kyushu University

Nakamura, Yasuhiko

Food Chemistry Institute, Faculty of Agriculture, Kyushu University

Murakami, Hiroki

Food Chemistry Institute, Faculty of Agriculture, Kyushu University

https://doi.org/10.5109/22855

出版情報：九州大学大学院農学研究院紀要. 18 (3)，pp.181-189，1974-06. Kyushu University バージョン：

権利関係 : 


\title{
Antitumoric Potentiality of Some Ascorbate Derivatives*
}

\author{
Hirohisa Omura, Yoshifumi Tomita, Yasuhiko Nakamura ${ }^{\dagger}$ \\ and Hiroki Murakami
}

Food Chemistry Institute, Faculty of Agriculture,

Kyushu University, Fukuoka

(Received February 18, 1974)

\begin{abstract}
In view of importance of reductones which has been emphasized in our institute on the basis of the studies concerning the connection of food constituents and cancer, the antitumoric potentiality of some derivatives of ascorbic acid was investigated using sarcoma-180. The potentiality of dehydroascorbic acid was confirmed by administering it of higher purity than that employed in the preceding study, even in the experiments of much longer period. Erythorbic acid and its oxidized form, dehydroerythorbic acid, have also the antitumoric potentiality, although with less efficiency than ascorbic acid and dehydroascorbic acid. As observed with reductones, viscosity of DNA was reduced by erythorbic or dehydroerythorbic acid in the presence of $\mathrm{Cu}^{2+}$. Ascorbyl-monopalmitate which has also enediol group caused some repression of the growth of tumor too. However, when oxidized form of enediol group in dehydroascorbic acid had been blocked with o-phenylenediamine, decomposing ability on DNA as well as the antitumoric potentiality of dehydroascorbic acid were lost. Thus, in this study, some additional support were presented to our demonstration that the initial step in cancer repression by reductones may be due to the appropriate depolymerization of DNA.
\end{abstract}

\section{INTRODUCTION}

In a series of studies on antitumoric constituents of foods, importance of reductones was emphasized (Yamafuji and Murakami, 1968; Murakami and Yamafuji, 1968, 1969a, 1969b ; Yamafuji et al., 1970). It was especially significant that ascorbic acid (AA) and its oxidized products, dehydroascorbic acid (DAA) and 2,3-diketogulonic acid (DKG), repressed the growth of implanted sarcoma180 (Nakamura and Yamafuji, 1968; Yamafuji et al., 1971b). However, there are some problems concerning the antitumoric potentiality of DAA which showed the highest activity among them, because DAA preparation of relatively low purity had been employed and the assay of longer period was lacking for the study. The present paper reports the antitumoric potentiality of purified DAA and some derivatives of AA.

\footnotetext{
* The present study was reported at the 27 th annual meeting of the Japanese Society of Food and Nutrition on 17th May, 1973.

t Present address: Department of Domestic Sciences, Faculty of Education, Kagoshima University, Kagoshima.
} 


\section{MATERIALS AND METHODS}

\section{Dehydroascorbic acid (DAA)}

DAA was prepared as follows. According to Euler (1955), AA was oxidized to DAA with o-benzoquinone and the crude DAA preparation was refluxed in absolute acetone for $\mathbf{2}$ days by the procedure of Kurata and Sakurai (1967). Although DAA was more or less crystallized during the procedure, acetone was removed in vacuo and the solution was then cooled. DAA was filtered, washed with absolute alcohol and dehydrated to dryness in a desiccator in vacuo. M.P. 224 ${ }^{\circ} \mathrm{C}$ (decomp.). Anal. Found: C, 41.59; H, 3.68. Calcd. for $\mathrm{C}_{6} \mathrm{H}_{6} \mathrm{O}_{6}: \mathrm{C}, 41.39$; $\mathrm{H}, 3.47 \%$. Purity of the preparation was estimated as $89.4 \%$ by the assay of polarography (Kajita and Senda, 1972). The IR spectrum (KBr disk method) has the strong absorption band in the region of $1750 \mathrm{~cm}^{-1}$ attributed to $r$-lactone, but not the band of $\mathrm{C}=\mathrm{C}$ bond of $\mathrm{AA}$ at about $1670 \mathrm{~cm}^{-}$. UV absorption of DKG at $295 \mathrm{~nm}$ was not observed, which had been estimated in the crude preparation employed in the preceding study (Nakamura and Yamafuji, 1968; Yamafuji et al., 1971b). However, by ascending paper chromatography with butanol: acetic acid: water (4: 1: 1), a primary spot and very weak one with Rf value of respective 0.34 and 0.10 were detected upon spraying with phenylhydrazine. The latter seemed to be DKG contaminated or formed from DAA during the analysis. On the other hand, a single spot of DAA was detected on thin layer chromatogram.

\section{Erythorbic acid (EA)}

EA was obtained from Fujisawa Pharmaceutical Co., Ltd. by courtesy of Dr. T. Kajita of Nara Women's University.

\section{Dehydroerythorbic acid (DEA)}

DEA was prepared from EA according to the procedure of DAA preparation mentioned above. M.P. $210^{\circ}$ C. Anal. Found: C, 41.44; H, 3.65. Calcd. for $\mathrm{C}_{6} \mathrm{H}_{6} \mathrm{O}_{6}: \mathrm{C}, 41.39 ; \mathrm{H}, 3.47 \%$. As the case of DAA, the IR spectrum of DEA showed a strong absorption band of $\gamma$-lactone, but not the band of $\mathrm{C}=\mathrm{C}$ bond. Only a spot was detected by paper chromatography conducted under the same condition with that for DAA.

\section{Ascorbyl monopalmitate (AA-Palm)}

AA-Palm was obtained from Nippon Roche K. K. by courtesy of Dr. T. Fujii. By thin layer chromatography with chloroform: methanol: acetic acid: water (80: 10: 8: 2), a single spot with $\mathrm{Rf}$ value of $0.92-0.93$ was detected by spraying with indophenol reagent. It shows no appreciable contamination of other reductive substances.

\section{Condensation product of DAA with o-phenylenediamine (DAA-OPD)}

DAA-OPD was prepared as follows according to Ezaki et al. (1963). AA $(1.76 \mathrm{~g})$ was dissolved in the mixture of $10 \mathrm{ml}$ water and $12 \mathrm{ml}$ ethanol and o-phenylenediamine $(2.1 \mathrm{~g})$ was then added. After standing in a cold room, yellow crystalline was obtained and recrystallized from ethanol. M.P. $180^{\circ} \mathrm{C}$. Anal. Found: 60.82; H, 5.32; N, 15.65. Calcd. for $\mathrm{C}_{18} \mathrm{H}_{18} \mathrm{O}_{4} \mathrm{~N}_{4}: \mathrm{C}, 61.01, \mathrm{H}, 5.12$, $\mathrm{N}, 15.81 \%$. The IR spectrum of the product was consistent with that by Ezaki 
et al. (1963) and showed free from any carbonyl group.

\section{Assay of antitumoric poetntiality}

Assay was performed principally as follows.

a) Test animal Male ddN mice aged 4 weeks, weighing an average of about $20 \mathrm{~g}$ each were obtained from the Breeding Center, Medical Faculty, Kyushu University. Mice were fed with a diet from Oriental Yeast Co.

b) Tumor Sarcoma-180 ascites cells, which had been obtained from the Cancer Institute, Medical Faculty, Kyushu University and maintained in our institute, were used as solid tumor, because the ascites cells changed easily to a solid form after subcutaneous inoculation. Preliminary tests revealed that the number of ascites cells inoculated intraperitoneally was not sufficient for the test in a week, but ascites cells could grow in a pure cultural state in this period. The cell concentration in ascites reached the maximum $\left(2 \sim 3 \times 10^{8}\right.$ cells/ $\mathrm{ml}$ ) at the 8th day, and then reduced as the increase of ascites. The cells were spherical and of about the same size. They did not aggregate in every stage during the growth of cells. While ascites were sometimes colored with blood, it did not disturb the implantation. Ascites cells at the 8th day after inoculation were the most favorable to transplant for the experiment or the maintenance of the cell clone. The animals died from 2 to 3 weeks after inoculation of the cell. Although the successful minimum cell number for implantation is about $3 \times 10^{5}$ cells, $2 \times 10^{6}$ cells were usually implanted to a mouse.

To examine the antitumoric potentiality, $0.2 \mathrm{ml}$ ascites of the 8 th day were diluted with Ringer's solution to give the final concentration of $10^{7}$ cells $/ \mathrm{ml}$. The diluted ascites were inoculated subcutaneously at axilla. Success of the inoculation was found by the knob formation in about a week. The inoculation near flank caused a disappearance of the knob, and that near head caused the mouse's death before the sacrifice to measure the tumor weight. Tumor was grown up to give an average weight of 3 to $5 \mathrm{~g}$ in 2 weeks.

c) Evaluation of the effect A reagent was usually dissolved in the sterilized Ringer's solution or the mixture ( $\mathrm{pH} 5.5$ ) of Ringer's solution and $0.01 \mathrm{M}$ acetate buffer. The reagent solution was administrated by subcutaneous injection near the inoculated place daily or every other day after inoculating the tumor. The dose was $0.2 \mathrm{ml}$ of $0.017 \mathrm{~m}$ moles for every reagent. For the control group, only the solvent was injected similarly. As the growth of tumor was affected by the condition of animals, the average and the deviation of body weight of animal in each group was equalized. One group consisted of 10 mice. Before death by tumor growth, they were sacrified to measure the tumor weight on the 2nd or 3rd week. As described in detail (Iio and Yamafuji, 1968), the tumor was removed and weighed. The repression ratio was estimated by dividing the average tumor weight in the test group by that in the control.

\section{Estimation of viscosity of DNA solution}

The time course of the viscosity of the reaction mixture was estimated at $37^{\circ} \mathrm{C}$ in an Ostwald's viscometer. The final concentration of the reaction mixture was as follows: calf thymus DNA, $100 \mu \mathrm{g} / \mathrm{ml}$ SSC $(0.15 \mathrm{M}$ sodium chloride and $0.015 \mathrm{M}$ sodium citrate) ; phosphate buffer ( $\mathrm{pH} 7), 0.1 \mathrm{M}$; test reagent, 1 
$\mathrm{mM} ; \mathrm{CuSO}_{4}, 0.2 \mathrm{mM}$.

\section{RESULTS AND DISCUSSION}

\section{Dehydroascorbic acid}

In the preceding studies (Nakamura and Yamafuji, 1968; Yamafuji et al., 1971b), it was found that DAA showed the highest antitumoric potentiality compared with AA and DKG. However, DAA employed was prepared by oxidizing AA with iodine according to the modified procedure of Kenyon and Munro (1948) and consisted of $66 \% \mathrm{DAA}, 10 \% \mathrm{DKG}, 12 \% \mathrm{AA}$ and $22 \%$ unknown substances. In order to confirm the antitumoric potentiality of DAA, activity was repeatedly examined using much purified preparation of DAA. On the other hand, because the antitumoric potentiality had been usually estimated in a short period, assay of longer period was also carried out.

Similar to the preceding study, $\mathbf{0 . 2} \mathrm{ml}$ DAA solution (containing $3 \mathrm{mg}$ or about $0.017 \mathrm{~m}$ moles DAA; $150 \mathrm{mg} / \mathrm{kg}$ ) was subcutaneously injected once a day for 10 times from the next day after implanting the tumor in the "10-injection group." However, in the "28-injection group," DAA administration was continued then every other day until the 28th day. On the 29th day, tumor was weighed in all groups and the result was shown in Table 1.

Table 1. Antitumoric potentiality of DAA.

\begin{tabular}{crcc}
\hline Group & Body weight ${ }^{1)}, \mathrm{g}$ & Tumor weight ${ }^{12}, \mathrm{~g}$ Repression, 96 \\
\hline Control & $44.0 \pm 1.2$ & $13.6 \pm 0.8$ & \\
10-inj. & $35.4 \pm 3.5$ & $5.5 \pm 1.7$ & 60 \\
28-inj. & $31.6 \pm 2.0$ & $4.3 \pm 1.5$ & 68 \\
\hline
\end{tabular}

1) Mean \pm S.E. ; body weight includes tumor weight.

As shown in Table 1, the antitumoric potentiality of DAA was confirmed. Prolonged administration seemed to increase more or less the repressing effect.

Simultaneously, the changes in average body weight of mice and average diameter of tumors during the test period were estimated. Fig. 1 suggested that effect of administration of DAA on mice is not remarkable, because the increase of net body weight, which had been estimated by subtracting tumor weight from body weight, in the test groups was not inferior to that in the control.

Similar antitumoric potentiality was established by administering another purified DAA preparation supplied from Fuso Chemicals K. K., Osaka too.

On the other hand, mice were divided into 2 groups. One group was administered with DAA every day for 1 week after implantation of tumor and the other group was administered for 1 week and then every other day for additional 11 weeks. Elongation of life span by continuous administration of DAA was observed as shown in Fig. 2. Thus, the antitumoric potentiality of DAA was certified even in the test of longer period with highly purified preparations too. 


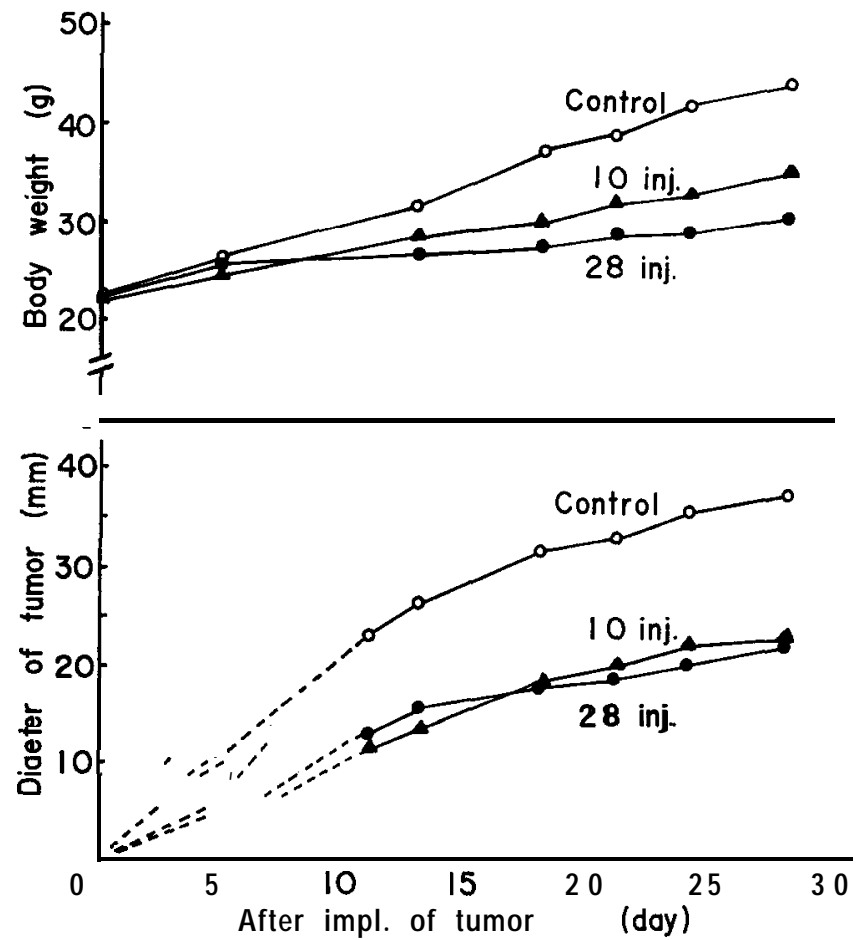

Fig. 1. Effect of DAA administration on growth of mice and tumor.

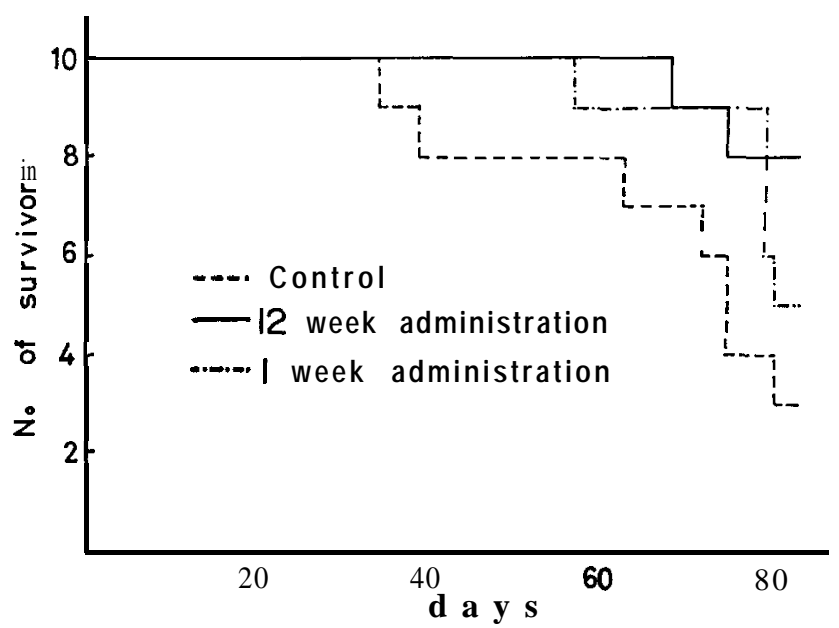

Fig. 2. Antitumoric potentiality of DAA in the test of longer period.

\section{Erythorbic Acid and Dehydroerythorbic Acid}

On assuming that the antitumoric potentiality of AA and its oxidized products is attributed to the function of reductones, it was presumed that enediol or its oxidized group in molecule takes an essential part and that their isomers, 
EA and DEA, must have the potentiality similarly. Therefore, the antitumoric potentiality was estimated for them. EA or DEA was administered in the same way as DAA, but the tumor was weighed on the 15 th day in all groups. In the " $\mathrm{Cu}^{2+}$ added group," $55 \mu \mathrm{g} \mathrm{CuSO}{ }_{1}(0.34 \mu$ moles : $2.75 \mathrm{mg} / \mathrm{kg})$ were simultaneously injected with EA or DEA.

Table 2 shows the repression of the growth of tumor by EA and DEA, although the efficiencies were less than those of AA and DAA. Some possible reasons might be explained by the difference in metabolism or in permeability through cell membranes between $\mathrm{L}$ and $\mathrm{D}$ forms of the reagents (Teruuchi and Okamura, 1972). The definite accelerating effect of $\mathrm{Cu}^{2+}$ was not observed.

Table 2. Antitumoric potenciality of EA and DEA.

\begin{tabular}{lcccc}
\hline \multicolumn{1}{c}{ Group } & & Body weight ${ }^{1)}, \mathrm{g}$ & Tumor weight”, g Repression, \% \\
\cline { 1 - 2 } \cline { 3 - 5 } Control & & $32.6 \pm 2.2$ & $4.4 \pm 1.0$ & \\
EA & & $29.6 \pm 1.7$ & $3.1 \pm 0.7$ & 30 \\
$\mathrm{EA}+\mathrm{Cu}^{2+}$ & & $30.5 \pm 1.5$ & $2.6 \pm 0.4$ & 41 \\
\hline Control & $33.3 \pm 1.9$ & $5.9 \pm 0.6$ & \\
DEA & & $28.4 \pm 0.8$ & $3.6 \pm 0.5$ & 41 \\
DEA $+\mathrm{Cu}^{2+}$ & $27.4 \pm 1.1$ & $3.3 \mathrm{t} 0.4$ & 45 \\
\hline
\end{tabular}

1) Mean \pm S.E. ; body weight includes tumor weight.

On the basis of many studies, Yamafuji (1970) and his groups (1971a, 1971c) demonstrated the hypothesis that appropriate breaks in chromosomal DNA may bring about virogenesis, mutagenesis, carcinogenesis, carcinostasis or cellular differentiation as one of the primary initial processes. In fact, it was established that DNA was depolymerized by the action of many substances which induce differentiation or anomalization of cells and that the breaking action of them on DNA in vitro was enhanced in the presence of $\mathrm{Cu}^{2+}$. Therefore, effect of EA and DEA on viscosity of DNA solution was estimated with or without

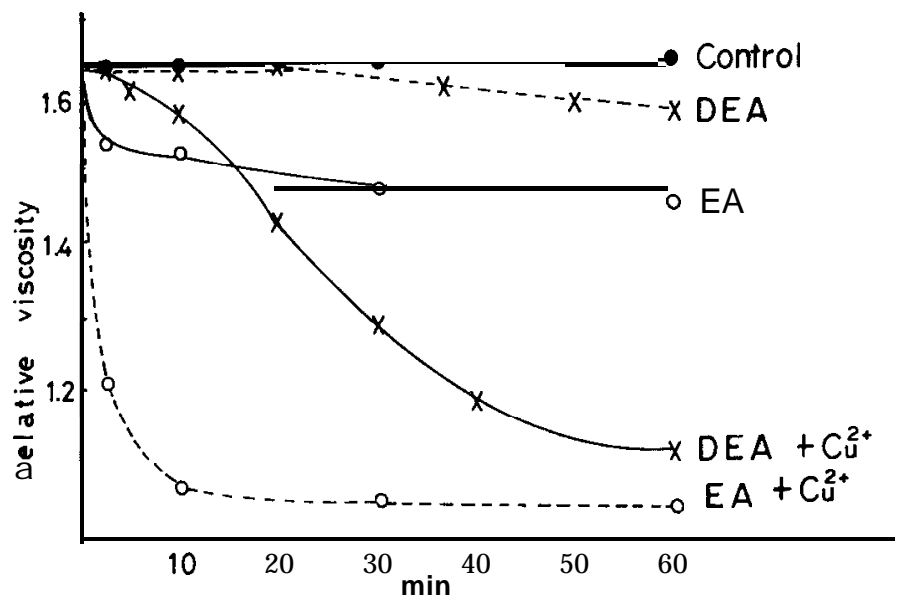

Fig. 3. Effect of EA or DEA on viscosity of DNA solution. 
$\mathrm{Cu}^{2+}$ and indicated in Fig. 3.

The viscosity of DNA decreased a little by the action of EA, but it was remarkably intensified in the presence of $\mathrm{Cu}^{2+}$. Although no effect was found in the case of DEA, addition of $\mathrm{Cu}^{2+}$ clearly provoked the lowering the viscosity of DNA solution after a few minutes. However, both $\mathrm{Fe}^{2+}$ and $\mathrm{Fe}^{3+}$ did not strengthen the action of the reagents. $\mathrm{Cu}^{2+}$ alone, of course, caused no decrease in viscosity of DNA. The result suggests the possibility to break DNA by the action of EA or DEA with $\mathrm{Cu}^{2+}$, while it can not conclude only by the decrease in viscosity, on the basis of similar experiments.

\section{Ascorbyl monopalmitate}

Palmityl and stearyl mono or diesters of AA were recently developed as fat-soluble vitamin $\mathrm{C}$ and their various application in food industry was expected as food additive or antioxidant material, because they have the similar physiological function with that of AA (Inagaki and Kawaguchi, 1966). Since they also contain the enediol group in the molecule, antitumoric potentiality of AA-Palm was examined. The test was carried out under the same condition as the case of EA and DEA, by administering $7 \mathrm{mg}$ AA-Palm (about $0.017 \mathrm{~m}$ moles ; $350 \mathrm{mg} / \mathrm{kg}$ ). However, AA-Palm was dissolved in propylene glycol and injected, because it is insoluble in water. The control group received, therefore, propylene glycol only. As shown in Table 3, AA-Palm possessed an antitumoric potentiality to some degree as expected.

Table 3. Antitumoric potentiality of AA-Palm.

\begin{tabular}{|c|c|c|}
\hline Group & Body weight”, g & Tumor weight ${ }^{11}, \mathrm{~g}$ Repression,,$\%$ \\
\hline Control & $28.0 \pm 1.4$ & $3.3 \pm 0.4$ \\
\hline AA-Palm & $28.7 \pm 1.0$ & $1.5 \pm 0.3$ \\
\hline
\end{tabular}

1) Mean \pm S.E. ; body weight includes tumor weight.

\section{Condensation product of DAA with o-phenylenediamine}

The experimental results so far obtained seem to support the above assumption that the antitumoric potentiality of $\mathrm{AA}$ and its derivatives might be attributed to the properties of reductone, especially to the enediol or its oxidized group in molecule. If these functional groups were blocked by other substance, the antitumoric potentiality would disappear. Therefore, DAA was condensed with o-phenylenediamine in the molar ratio of 1: 2 to block the all keto groups of DAA and the antitumoric potentiality of the product (DAA-OPD), 7-(1-glycerodihydroxyethyl)-13,14-furo(2,3-b ; 3,4-b')-diquinoxalin, was examined. DAA-OPD was administered similarly as AA-Palm to mice by dissolving it in propylene glycol, but $5.8 \mathrm{mg}$ DAA-OPD (about $0.017 \mathrm{~m}$ moles ; $290 \mathrm{mg} / \mathrm{kg}$ ) were injected.

As shown in Table 4, the remarkable low antitumoric potentiality less than $30 \%$ was observed for DAA-OPD. This may be explained by that the functional groups in DAA molecule are blocked with o-phenylenediamine and the antitumoric potentiality was lost, as expected. However, it is very difficult to conclude that DAA.OPD is effective for repression of tumor growth on this value. If 
Table, 4. Antitumoric potentiality of DAA-OPD.

\begin{tabular}{lccc}
\hline \multicolumn{1}{c}{ Group } & Body weight", g & Tumor weight ${ }^{11}, \mathrm{~g}$ Repression, \%6 \\
\hline Control & $28.0 \pm 1.4$ & $3.3 \pm 0.4$ & 30 \\
DAA-OPD & $29.4 \pm 1.2$ & $2.3 \pm 0.4$ & 30 \\
\hline
\end{tabular}

1) Mean \pm S.E. ; body weight includes tumor weight.

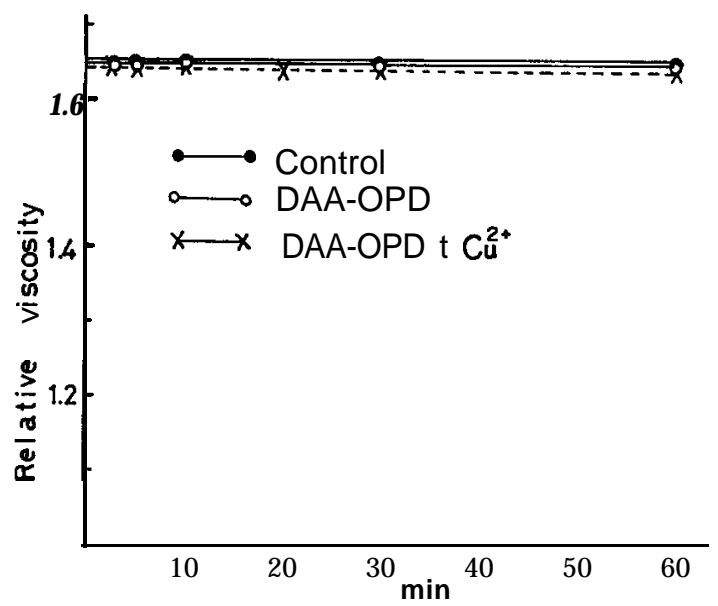

Fig. 4. Effect of DAA-OPD on viscosity of DNA solution.

any, it may be a cosequence of small amount of DAA possibly liberated from DAA-OPD in the body of mouse. For this reason, action of DAA-OPD on the viscosity of DNA solution in vitro was also examined. As shown in Fig. 4, the lowering effect of DAA-OPD could not be established even in the presence of $\mathrm{Cu}^{2+}$, suggesting that the reactivity of DAA with DNA was hindered by blocking the carbonyl group in the molecule of DAA.

Similary, reductone A, 5-methyl-3,4-dihydroxytetrone, derived from AA has also the antitumoric potentiality (Tomita et al. 1974) and the ability to depolymerize DNA. Thus, these experimental results emphasize the intimate correlation between the antitumoric potentiality and the reductive properties of reductones and support the Yamafuji's hypothesis that the appropriate breaks inDNA may be an initial step in the antitumoric action. In addition, some antitumoric substances may be explored on the basis of these observations.

\section{ACKNOWLEDGEMENTS}

The authors are indebted to Prof. Dr. D. Nomura for his useful guidance and to Dr. T. Kajita, Dr. K. Kawachi, Dr. T. Fujii, Fujisawa Pharmaceutical Co. Ltd., Fuso Chemicals K. K. and Nippon Roche K. K. for supplying the reagents. 


\section{R E F ER ENCES}

Euler, H. 1955 Entstehung von aci-Reduktonen. Arkiv Kemi, 8(8): 67-72

Ezaki, S., S. Kamiya and K. Hada 1963 Studies on the quantitative analytical method of L-ascorbic acid (Part 1). Bull. Shizuoka Women's Junior College, 9: 105-131

Iio, M. and K. Yamafuji 1968 Antitumor activity of bamboo-leaf polysaccharide. Sci. Bull. Fac. Agr. Kyushu Unir., 23(3): 113-118

Inagaki, C. and K. Kawaguchi 1966 Studies on the metabolism of fatty acid esters of Lascorbic acid. (1) Excretion and accumulation of ascorbic acid after administration of mono and dipalmitates of ascorbic acid. Vitamins (Japan), 34(3): 293-297

Kajita, T. and M. Senda 1972 Simultaneous determination of L-ascorbic acid, triose reduc tone and their related compounds in foods by polarographic method. J. Agr. Chem. Soc. Japan, 46(3): 137-145

Kenyon, J. and Munro, N. 1948 The isolation and some properties of dehydro-L-ascorbic acid. J. Chem. Soc., 1948: 158-161

Murakami, H. and K. Yamafuji 1968 Antitumor activity of lignin. Sci Bull. Fac. Agr. Kyushu Univ., 23(3): 103-111

Murakami, H. and K. Yamafuji 1969a Antitumor activity of catechol and its reaction with deoxyribonucleic acid. Sci. Bull. Fac. Agr. Kyushu Univ., 24(1): 13-17

Murakami, H. and K. Yamafuji 1969b Antitumor activities of polyphenols. Sci. Bull. Fac. Agr. Kyushu Univ., 24(1): 19-24

Nakamura, Y. and K. Yamafuji 1968 Antitumor activities of oxidized products of ascorbic acid. Sci. Bull. Fac. Agr. Kyushu Univ., 23(3): 119-125

Teruuchi, J. and M. Okamura 1972 Metabolism of vitamin C (IV) The uptake of ascorbic acid and isoascorbic acid by human erythrocytes. Vitamins (Japan), 45(4): 201-208

Tomita, Y., M. Eto, M. Iio, H. Murakami and H. Omura 1974 Antitumor potency of 5-methyl-3,4-dihydroxytetrone. Sci. Bull. Fac. Agr. Kyushu Univ., 28(3): 131-137

Yamafuji, K. 1970 Food, cancer and cytodifferentiation. Shukosha Co. Ltd., Fukuoka, Japan

Yamafuji, K., S. Iiyama and K. Shinohara 1971a Mode of action of steroid hormones on deoxyribonucleic acid. Enzymologia, 40(4) : 259-264

Yamafuji, K. and H. Murakami 1968 Antitumour potency of lignin and pyrocatechol and their action on deoxyribonucleic acid. Enzymologia, 35(3) : 139-153

Yamafuji, K., H. Murakami and M. Shinozuka 1970 Antitumour activity of dopa, dopamine, noradrenalin or adrenalin and their reaction with nucleic acid. Z, Krebsforsch., 73(2): 195-203

Yamafuji, K., Y. Nakamura, H. Omura, T. Soeda and K. Gyotoku 1971b Antitumour potency of ascorbic, dehydroascorbic or 2,3-diketogulonic acid and their action on deoxyribonucleic acid. Z, Krebsforsch., 76(1): l-7

Yamafuji, K., K. Shinohara, F. Yoshihara, M. Iio and Y. Torikai 1971c Enzymologia, 40(2): 107-116 